\title{
二組の双生児にみた脳性小児麻㾇について
}

\author{
長大整形外科教室（主任教授 永井三郎）鳥 羽 健 吾
}

\section{On Two Sets of Twins with Spastic Paralysis}

by

\section{K. Toba.}

Department of Orthopedic Surgery, Nagasaki University, School of Medicine,

(Direct. , Prof. S. Nagai).

\section{暂}

脳性小児麻瘏に就いての我が国に於ける報告は多数 あるが，双生児にみられた脳性小児麻㾰の報告例は少 く, 伊藤・田代氏の 5 組, 伊藤氏の 4 組, 木城・大島 氏の 1 組で両児共生存せる者は木城・大島氏の場合の みで而も Little 型で一卵性双生児である。

外国に於いても Thumnsの全ドイツより集めた 70 組, Siemens の 1 組, Stand の 2 組, Curtius, Jacobeus, Stiefler, Verschner, \一畉性各 1 組, Boeters u. Dittleの一卵性 2 組である。

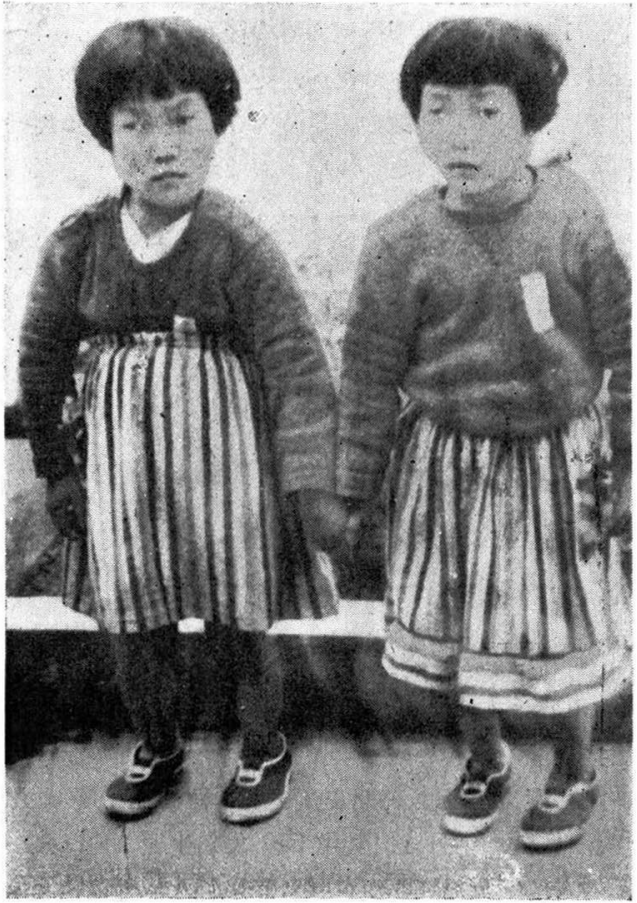

第 I 例
最近我々も一畉性と思われる両児共生存する脳性小 児麻瘏 1 組と畉性鑑別不明の脳性小児麻痷 1 組を経験 したので報告する次第である。

症例 I 患者 双生児 우8才 10 ケ月

既往歴 両児共満期産で頭位分婏, 安産で生下時体 重は第一児 420 多, 第二児は 400 多, 然し第一児は窒 息分婏で人工呼吸により呼吸開始せりという。文約 2 ケ月位汽 Cyanotisch であつたと云う。両児共混合 栄養で新生児黄㾝はさほど强くなく, 麻疹に罹患した 他は特記すぺき既往症はない。

両児共，首固定遅く第一児は 2 才で，第二児は 1 才 で這い始め，起立開始は第一児 3 才 6 ケ月で第二児は 3 才 7 ケ月，初期歩行は両児共 4 才であつたが痤性歩 行をし，よく転び易いということを，主訴として来院 于。

現 症 8 才 10 ケ月現在に計測せる体重身長等は 第 1 表の如くで 8 才の平均より体重身長共に劣り胸囲 だけが勝つている。

顔面は愚 鈍様で外斜視を有するが発音障碍は認め ず，皮膚粘膜に異常なく頸部淋巴腺腫脹なく，屚桃腺 は両児共幾らか肥大しているが発赤はない。心臓，肺

第 1 表

\begin{tabular}{|c|c|c|c|c|}
\hline & & 第 一兒 & 第 二 兒 & 平均 \\
\hline 身 & 長 & $99.4 \mathrm{~cm}$ & $96.0 \mathrm{~cm}$ & $118.8 \mathrm{~cm}$ \\
\hline 体 & 重 & $19.0 \mathrm{~kg}$ & $18.2 \mathrm{~kg}$ & $22.1 \mathrm{~kg}$ \\
\hline 胘 & 囲 & $62.0 \mathrm{~cm}$ & $62 . \mathrm{cm}$ & $58.4 \mathrm{~cm}$ \\
\hline 頭 & 囲 & $48.5 \mathrm{~cm}$ & $48.0 \mathrm{~cm}$ & \\
\hline
\end{tabular}

年令 8 才（第 $\mathbf{I}$ 例） 
膱，腹部等に異常は認められず，滕蓋腱，及びアヒレ 又腱反射は雨児共宎進しているが病的反射は共に証明 出来なかつた。

上肢 开时手指の運動は両乔共良好で，上肢の笳强 剛なく二頭膊筋，三頭朝筋の腱反射方進はない。

下肢 股関郎第一児 $165^{\circ}$ 屈曲位，第二児は $170^{\circ}$ 届曲位を保つが両览共自動的過珄展不能, 然し他動的

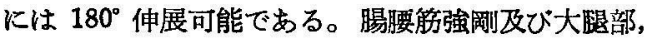
屈筇及び内転筋群强岡著明であつた。

滕関節引は第一览 $160^{\circ}$ 第二児は $170^{\circ}$ 屈曲位を保つが 両胃共他動的 $18^{\circ}$ 伸震可能であり，共に腓腹筋，ヒラ メ笳の强㓮著明。

足関節は第一少 $130^{\circ}$ 尖足位, $20^{\circ}$ 内転位を保ち第二 児は $125^{\circ}$ 尖足位, $20^{\circ}$ 内転位を保ち第二児は $125^{\circ}$ 秃 足位, $20^{\circ}$ 内転位を保つが他動的には $90^{\circ}$ 背届， $0^{\circ}$ 内 転位をとり得る。

第 2 表 智能檢查: 成縝

\begin{tabular}{|c|c|c|}
\hline & 第 一 兒 & 第 二 兒 \\
\hline 生 活 年 令 & 8オ10ケ月 & 8才10ケ月 \\
\hline 智 能 年 令 & 3 オとケ & 3才゙6ケ月 \\
\hline 智 能 指 数 & 39 & 39 \\
\hline
\end{tabular}

第 3 表 遗 傳 形 質 (例 I )

\begin{tabular}{|c|c|c|c|}
\hline & 第 一 兒 & 第 & 兒 \\
\hline 血液型 & 0 & & 0 \\
\hline 虹 彩 & 褐 色 & & $" 1$ \\
\hline 斜 視 & 外 斜 䏹 & & "I \\
\hline 頭 繁 & 黑 㓮 直 毛 & & $"$ \\
\hline 渦 毛 & 正中よ $y$ 稳左に 1 個 & & $1 /$ \\
\hline 皮庴 & 黄 白 色 & & "l \\
\hline 庙毛 & 長: $4.5 \mathrm{~cm} \quad \| 1: 1.0 \mathrm{~cm}$ & & $" l$ \\
\hline 鼻 & 尖:銛 背:稍 凹 & & $"$ \\
\hline 口 原 & 長: $3.5 \mathrm{~cm}$ 厚: $7 \mathrm{~mm}$ & 長: $3.5 \mathrm{~cm}$ & n 厚: $6 \mathrm{~mm}$ \\
\hline 外 耳 & ダーウイン結符なし & & "I \\
\hline 往 斑 & な & & $\|$ \\
\hline 齿 列 & 整 & & $" 1$ \\
\hline
\end{tabular}

歩行は股，及び膝関節を届曲し足関節は尖足及び内 転位とし両脚を交丒させ，痓直性でよく耺び易い。 智能検査成績は第 2 表の如くで著しく劣つている。 遣伝形犋は第 3 表の如くで全く相似し，これら形質 の面から推定すると一眆性双生児であると思われる。

第 4 装 垫例 I 芜 族 糜

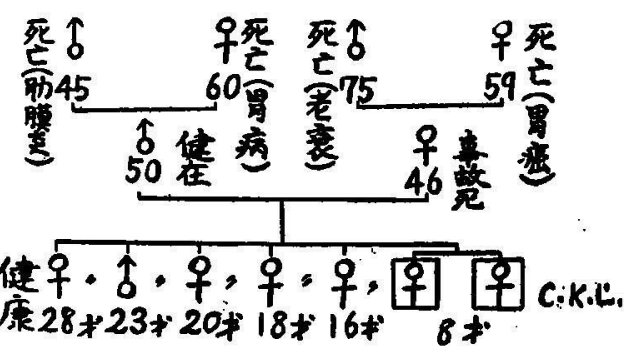

家族歴 第 4 表の如くで家柔には血族結婚なく大酒 家もいず雨親は性病, 特に梅毒を否定している。然し 耳親は患児入院治潦中，神経衰弱気味であつてときど き訳のわからぬことを云つていたと近親者はいらがと の後自動車事故により死亡している。

治 璙、下肢のマッサーヂ及び週 1 回パンピングを 行つていたがその後，膝及び足関節に対するストッフ エル氏手術を行い骨盤より前足部迄 ギプス包带を施 し， 1 ケ月後から歩行練習等の後癔法を行い， $2 \sim 3$ ろ月迄経過良好であつたが，その後次第に再発し 5 ヶ 月目には両脚を交丒し滕足関節を屈曲位とする㽷性歩 行を行う様になつた。

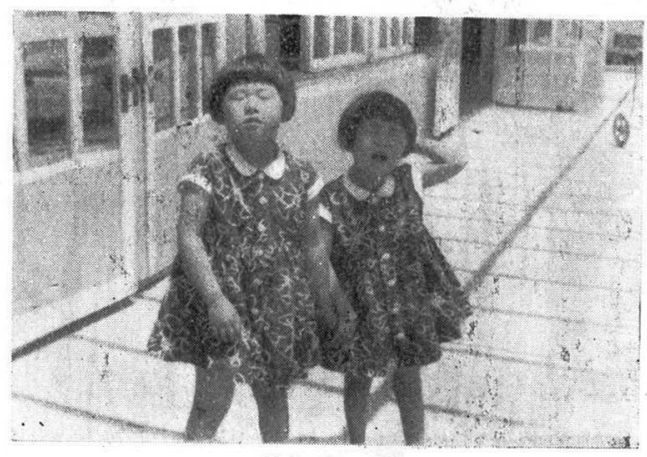

第， II: 例，

症例 II 患者—双生児 \& 6 才 既往症 分婏は满期安産頭位分婏で 鱾子等は用い ず，生下侍体重は両児共 550 多新生児黄瘨は強かつ

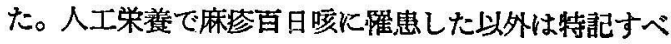
き既往症はない。 
首固定は第一児は， $7 \sim 8$ 万月第二児は 4 〜 万月 で, 坐り始めは両児共 10 12 方月. 起立開始は第一 児 1 年 6 名月，第二児は 2 才，歩行は第一児 2 才，第 二児は 2 年 6 ケ月で開始している。両児共痤直性で転 び易かつた。発音は第二児がいくらか障碍されている 程度である。

智能は両児共正常であつた。

第 5 表

\begin{tabular}{|c|c|c|c|c|}
\hline & & 第一兒 & 第二兒 & 本均 \\
\hline 身 & 長 & $89.4 \mathrm{~cm}$ & $85.8 \mathrm{~cm}$ & $104.7 \mathrm{~cm}$ \\
\hline 体 & 重 & $15.3 \mathrm{~kg}$ & $14.1 \mathrm{~kg}$ & $16.5 \mathrm{~kg}$ \\
\hline 脥 & 囲 & $48.2 \mathrm{~cm}$ & $46.1 \mathrm{~cm}$ & $52.0 \mathrm{~cm}$ \\
\hline 頭 & 国 & $44.5 \mathrm{~cm}$ & $37.5 \mathrm{~cm}$ & $49.6 \mathrm{~cm}$ \\
\hline
\end{tabular}

現 症 体重身長等は表 5 の如くで両児共 6 于の平 均より劣つており，第二児は第一児より更に少つてい る。

顔面は正常皮膚粘膜に異常なく胸部腹部に著変なく

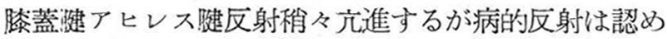
られず。

上肢 両児共, 上胶長左右等しく筋強剛を認めず, 上肢の運動は全く自由であり，二頭膊筇及び三就膊筋 反射は它進せず。

下肢 下肢長及び大腿及び下腿夙畔待両児共左右等 しく大眼部屈㬳内転朌群に軽度の強㓮を認めるが膝関 節拘縮は両児共に認められず。股及び滕関䬦门運動は 他動的に全方向に可能であるが，自動的には多少ぎこ ちない程度である下腿屈筋群にも軽度の筋強剛を認め るが足関節の運動は他動的に全方向に良好で自動的に は稍々緩慢である。

歩行は稍々痓性であるが相当距離泛の歩行は可能で ある。

·発音は第二児に軽度の障碍を認める。

遺后形質は第 6 表の如くで一応類似するが，身長体 重に或る程度に差があるので福田氏の分類による卵性 鑑別不明に属するものと思われる。

家族歴は表 7 の如くで父母共に健沗で性病を否定し ている，又血族結婚でもなく精神，神経病家系でもな く渏型児も居ない。

治療は歩行練習をさせたのみで充分に上手に歩行出 来る様になつて退院した。
第6 表 遗 傳 形 質 (例II)

\begin{tabular}{|c|c|c|c|}
\hline & 第 一 兒 & 第 & 兒 \\
\hline 血液型 & B & & B \\
\hline 虹. 彩 & 褐 & & "I \\
\hline 斜 視 & ᄂ & & " \\
\hline 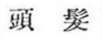 & 黑 秎 縮 毛 & & " \\
\hline 渦 毛 & 正 中 $に 1$ 個 & & "I \\
\hline 皮 䖉 & 黄 白 色 & & " \\
\hline 盾 毛 & 薄 & & "I \\
\hline 鼻 & 尖：鈍 背：凹 & & " \\
\hline 口原 & 匽: $5 \mathrm{~mm}$ 長: $3.4 \mathrm{~cm}$ & 厚: $5 \mathrm{~mm}$ & 長: $3.3 \mathrm{~cm}$ \\
\hline 外耳形 & ダーウイン結箁なし & & " \\
\hline 雀 球: & な & & " \\
\hline 博 列 & 不 & & " \\
\hline
\end{tabular}

第 7 表

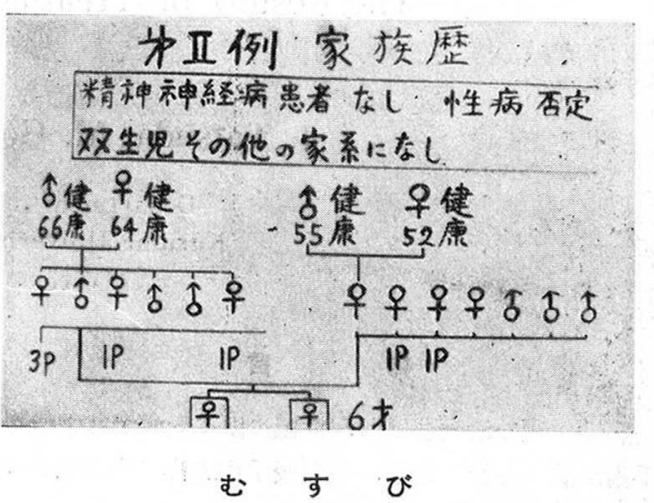

第 I例の第一児は咥息分姢であり第二児はその様な ことはなかつた点母親が神経衰弱気味で事故死した点 を考拿わせると, その発生原因に興味がもたれる。

又窒息分㜚であつた第一児が身体的即身長，及び体 重等にいくらか第二児より勝つていること。又両児共 ストッフェル氏手術を行い大体同洔期に再発したこと 等以上脳性小児麻瘦双生児患児の遺伝的負荷及び環境 的影響が或る程度，観察されて面白いと思われた。

又第 II例の如く分娭障碍も遺伝的負荷なく生じた脳 性小児麻瘦双生児の例も合わせて 報告した次第であ る。 


\section{文 嗝}

1. 木城・大島：一卵性双生児にみたリットル氏病 症例 (日整会雑誌 25 巻, 326)

2. 今・早川・西井 : Little 氏病の統計的観察（児 科診療 8 巻, 5 号, 294)

3. Stiefler G. : Little'sch Kranklheit bei Geschwistern und bei $Z$ willingen. (J.f. Psychol. u. Neurol. 37 : 362 372. Aug. 28)

追 加

九大整形 古賀順一 只今の御演説に関連してつい最近, 我々の数室で双
児ではなかつたが，姉弟 2 人，全く同じ症状で脪波の 所見も完全に同じ波形を示したといら例があつたの で、リットル氏病発現の家族的因子について，調味を そつられた訳であるが，教室の石原氏はリットル氏病 100 例について詳細に病因の調査を行い，血旗結婚そ の他の家族的因子が可成り含まれる事を認めている。

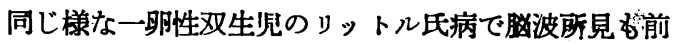
頭優勢, slow activity である事まで，全く同一であ つたと云う浦原氏の報告があつたので，追加した。

\section{筋 性 斜 頸 の 治 療 成 績}

\begin{tabular}{|c|c|c|c|c|}
\hline \multirow[t]{3}{*}{$\begin{array}{l}\text { 久留米大学医学部整形外科教室 } \\
\text { (主任 城圭教授) }\end{array}$} & & 立 & 田 & 丞 \\
\hline & 副 手 & 五 & 反 & 田 \\
\hline & 専攻生 & 百 & & \\
\hline
\end{tabular}

The Results of Treatments of Muscular Torticollis

by

\section{J. Tatsuda, M. Gotanda \& T. Hyakutake}

Department of Orthopedic Surgery, Kurume Univeristy, School of Medicine

(Direct.; Prof. S. Miyagi)

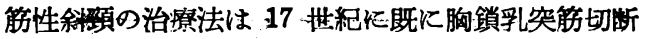
手術が試みられて居り, その後手術操作にる改善が加 兄られ，汉乳児期に於けるマッサージ療法る効果を举 げて居るが諸家の意見は可及的早期に治㙩を始むべき 事に一致しているけれどす, その方法に就いては各好 む所に従い一定せる方法は採用されて居ない現状であ る。

吾々は久留米大学医学部整形外科教室に於いて, 昭 和 27 年以降昭和 31 年 6 月迄に診療した筋性斜頸患 者 75 名の治潦成績を直接检診又は通信によつて調查 し, 些か知見を得たので報告し諸賢の御批判, 御教示 を乞うあのである。

\section{治 潦成}

75 例中性別は 037 名, 广 38 名で左右別では左
28 名, 右 47 名（1：1.67） となつて居り, 分婏状態 は安産 66名 $(88 \%$ ) 難産 9 名（鈷子分婏 5 , 人工蘇

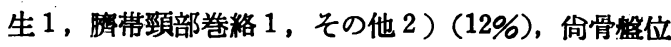
分娩 15 名があり，合併症として両側性先天性股関節 脱臼を有するるの 4 名があつた。これらの5ち治療成 樍を調査し得たるのは, 来㟝 25 名, 通信によるるの 37 名, 計 52 名である。治療成績は斜頚及び胸鎖乳 突筋の状況, 顔面頭部の左右不均弯, 脊椎側彎を主目 標として便宜上次の三群に分つて检討した。”

便 : 斜頸なく顔面頭部の不均弯る殆んど消失して, 完全治療と見做し得るるの。

良: 斜頸なく筋短縮緊張消失或いは軽快し，主とし て顔面頭部の不均齊又は脊椎側彎の残存するもの。

不可 : 斜頸めり筋短縮緊張を認め頭蓋側灣の存する ठの。

調査患者 52 例中保存的療法を行つた者は 40 名で, 